\title{
Pirateri og propaganda
}

af forskningsbibliotekar Jesper Düring Jørgensen

Det var en historie, aviserne forfulgte med stor interesse gennem adskillige uger i begyndelsen af året 1918, og da aviserne stoppede, tog bogforlagene fat.

Første nedslag var et officiøst tysk telegram til de danske aviser, hvori det hed, at hjælpekrydseren Wolf var vendt lykkeligt tilbage til Tyskland efter et 16 måneder langt togt på verdenshavene. I telegrammet, der var fint anbragt bl.a. på Politikens forside, hed det, at Wolf ud over et stort antal fanger fra kaprede skibe havde hjembragt et rigt bytte af flere sjældne metaller og andre nyttige sager til den betrængte tyske krigsøkonomi.

Allerede dagen efter blev det tyske telegram fulgt op af en reportage, - lige så fremragende placeret $i$ aviserne, som telegrammet havde været. - Overskriften var om muligt endnu mere sensationel og tillige lettere mystificerende: "Wolfs fangeskib strandet på Skagen".

Nedenfor fulgte derpå en beretning om strandingen, der vist må siges at høre til de mere usædvanlige. Historien var følgende:

Den spanske damper Igotz Mendi var sent på året 1917 blevet opbragt af Wolf et sted i Sydatlanten. At det var et neutralt skib, gjorde intet til sagen i det givne øjeblik. Under trussel om øjeblikkelig sænkning havde den spanske kaptajn fulgt enhver ordre, der blev givet fra den tyske hjælpekrydser. Formålet med opbringelsen af Igotz Mendi var i øvrigt dobbelt. For det første havde Wolf brug for den kullast, som Igotz Mendi medførte, men dernæst havde krydseren stærkt brug for skibet Igotz Mendi. På sit lange togt på verdenshavene havde Wolf inklusive Igotz Mendi kapret 14 større og mindre skibe og havde som følge af denne energiske virksomhed mere end 200 mennesker af alle køn og hudfarver ombord som fanger fra de opbragte skibe foruden sin egen besætning på mere end 300 mand. At pladsen under dæk var mere end trang, siger sig selv, ligesom 


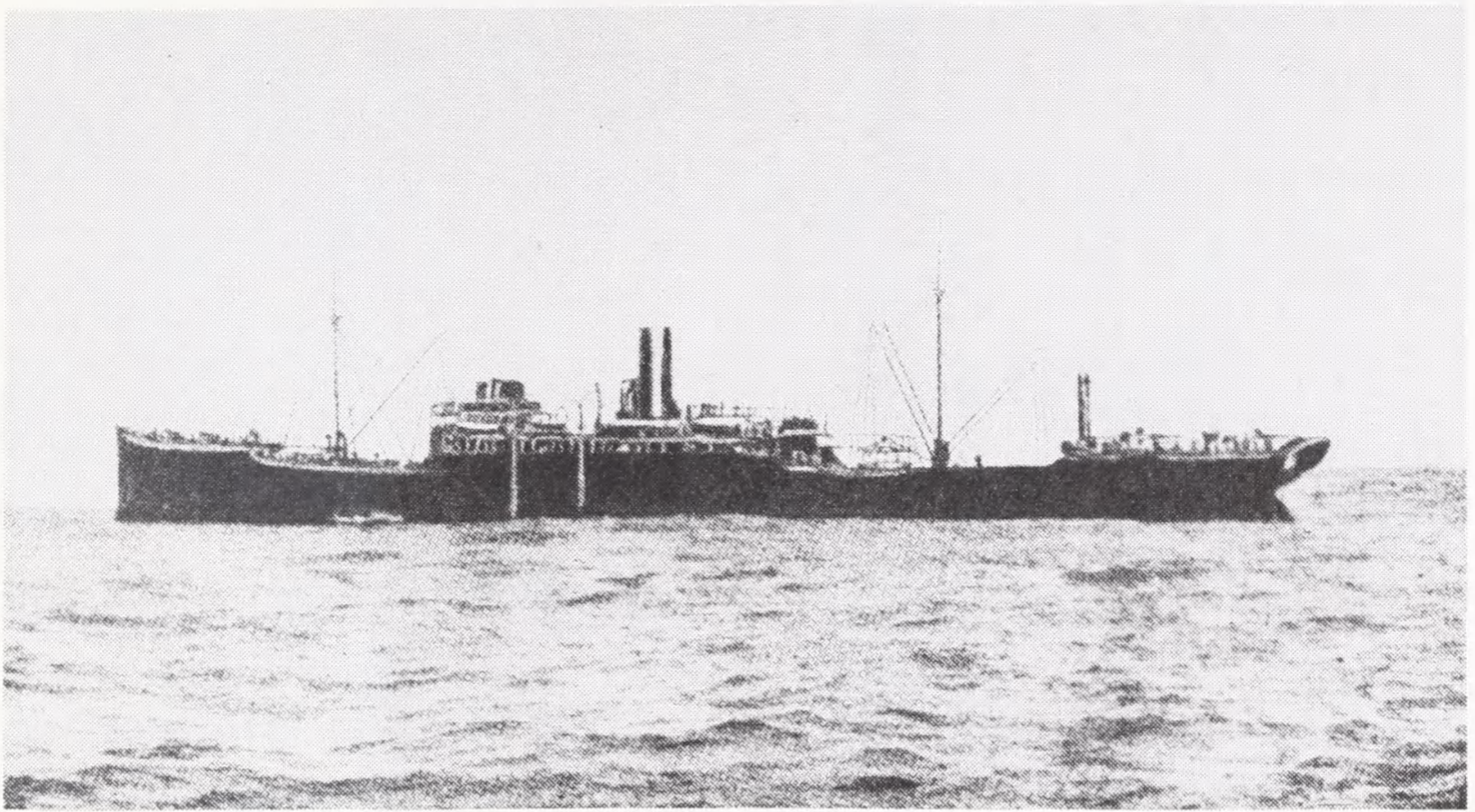

Hjælpekrydseren Wolf.

også forsyningssituationen efterhånden var blevet yderst anstrengt. Af disse årsager kom den store spanske damper på et særdeles belejligt tidspunkt som et bekvemt bytte. En god del af fangerne overførtes til Igotz Mendi, hvor en tysk prisebesætning med kaptajnløjtnant Rose i spidsen overtog kommandoen.

Med diskret afstand imellem sig fortsatte de to skibe nordpå gennem Atlanterhavet vest om De britiske Øer på respektfuld afstand af sejlruter og krigszone. Hensigten var fra en position syd for Island at liste østpå til Norske-kysten, ind bag den beskyttende norske tremile-zone og sydpå, tværs over det farlige Skagerak, der var krigszone, og herfra i ly af Jyllands østkyst sydpå til Kiel. For ikke at vække opsigt skulle de to skibe gennemføre turen med et par dages mellemrum. Wolf afgik som første skib og skulle afvente Igotz Mendis ankomst ved indløbet til Lillebælt, således at begge skibe i følge og i triumf kunne anløbe Kiel.

Dette var hensigten, men det blev ikke resultatet, idet Wolf måtte lægge til i Kiel uden sit fangeskib.

På Igotz Mendi havde man intet søkort over Skagerak og de øvrige danske farvande, da man ikke havde forestillet sig, at damperen skulle komme i nærheden af dem. I det tågede vejr og med utilstrækkelige søkort tog den tyske prisebesætning derfor fatalt fejl af Skagen Rev Fyrskib og fyret inde på land, og stranding blev følgen. Den tyske prisebesætning forsøgte at bluffe sig til assistance fra Switzers bjergningsselskab, men da den danske krydser Diana bordede Igotz Mendi, opdagedes det, hvilken rolle den var blevet tildelt. Skibet sattes 


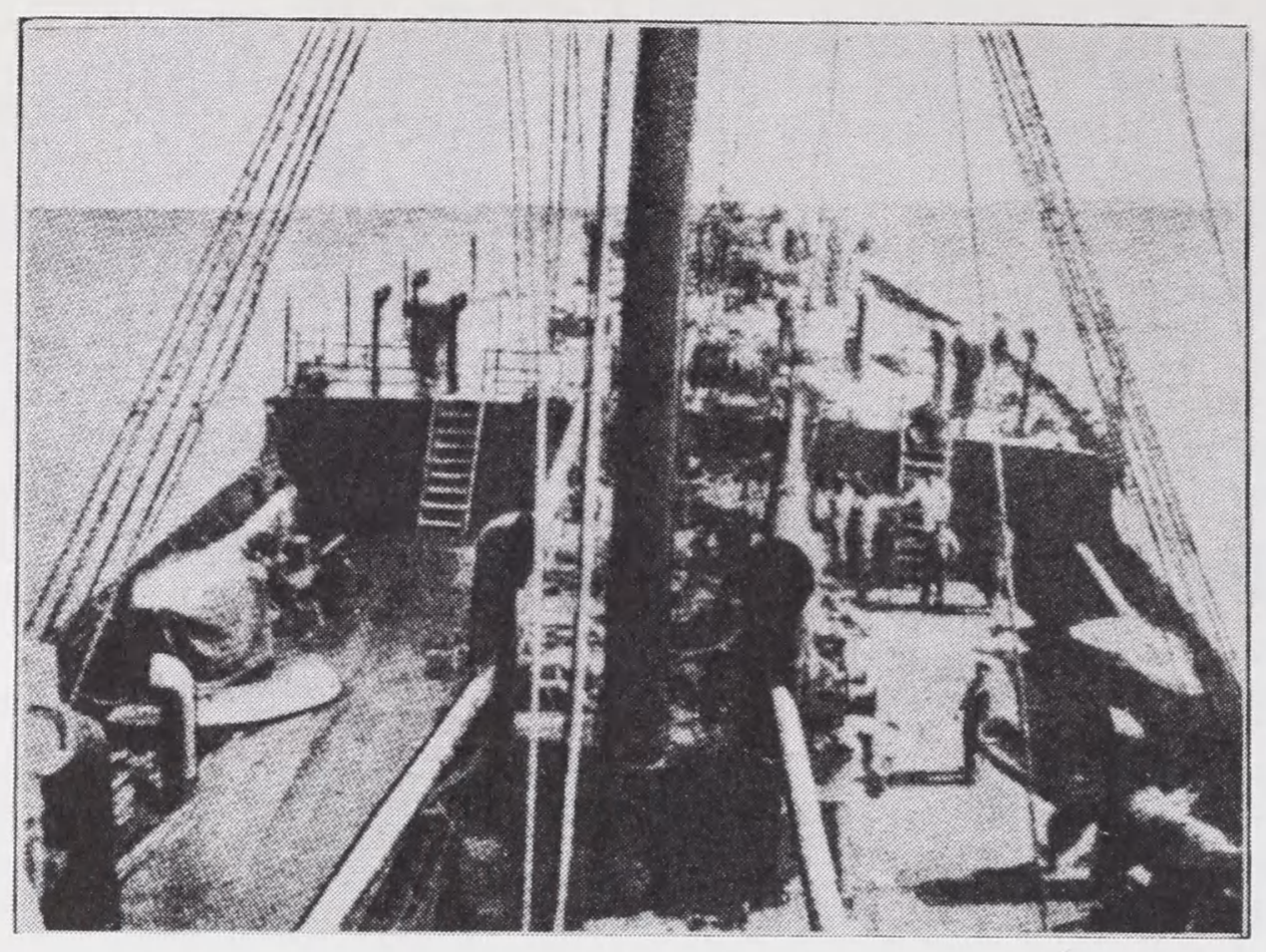

Forskibet på Wolf, kanonerne ses tildækket og gemt bag rælingen.

under bevogtning af enheder fra den danske flåde, og man gav tyskerne en frist på 48 timer til at komme fri ved egen hjælp. På et tidspunkt dukkede en ukendt u-båd op og begyndte signaludveklsling med Igotz Mendi, men den blev jaget bort af de danske skibe. Da det ikke lykkedes at få Igotz Mendi af grunden inden udløbet af den fastsatte frist, måtte prisebesætningen lade sig internere. Fangerne blev sat fri og bjergedes fra damperen af redningsvæsnet på Skagen.

Den officielle betegnelse for Wolf var "hjælpekrydser", en betegnelse, der i dette tilfælde dækkede over en almindelig fragtdamper på godt 6000 brutto registertons, $135 \mathrm{~m}$ langt, $17 \mathrm{~m}$ bredt og med en dybgang på $8,25 \mathrm{~m}$, udstyret med en maskinkraft, der tillod en maximumfart på 11,5 knob. Men ud over disse almindelige karakteristika var der intet almindeligt ved Wolf.

Indenfor de sorte skibssider fandtes forskellige skjulte installationer: En 15 $\mathrm{cm}$ kanon, kamufleret som lossebom, fire hurtigtskydende $11 \mathrm{~cm}$ kanoner, skjult bag rælingen, der hurtigt kunne vippes ned, desuden fire torpedorør og fire maskinkanoner.

Last ud over en lille vandflyver, kul, proviant og andre forsyninger til den 350 mand store besætning: 500 søminer.

Efter chefens, Fregattenkäpitän Nergers egen vurdering, var dette en armering, der gjorde Wolf stærk nok til at tage kampen op mod en mindre krydser, men dette var ikke opgaven. Ordren til Wolf var derimod "at ødelægge fjendtlig 


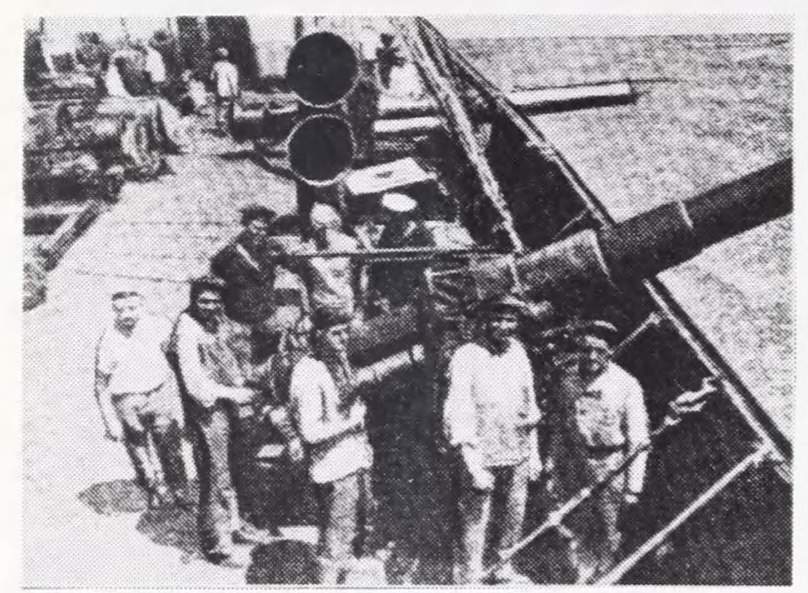

Kanonpudsning på Wolf.

Skibsfart på de fjerne Have, navnlig i Det indiske Ocean; at føre Handelskrig og udrette anden Krigstjeneste, i første Linje Udlægning af Miner". ${ }^{1}$

Sådan lød ordren i al enkelhed, men let beordret, er ofte svært udført.

Uden at gøre væsen af sig var Wolf stået ud fra Kiel en tåget novembernat i 1916 med kurs mod farvandet omkring de sydafrikanske havne. Som en tilsyneladende skikkelig fragtdamper nåede den uden besvær farvandet omkring Durban. Her begyndte hjælpekrydserens aktiviteter.

Den teknik, kaptajn Nerger anvendte, var simpel nok. Takket være udseendet som fragtdamper kunne Wolf uden opmærksomhed nærme sig havne, som var kontrolleret af den allierede søfart, og i ly af mørket kunne den lægge sine miner strategisk rigtigt i de ruter, som den allierede skibsfart fulgte. Ombord havde Wolf et efter tidens norm særdeles kraftigt radioudstyr, således at den kunne opfange de allieredes radiokommunikation på passende afstand. Herved opnåedes to fordele. For det første var Wolf i stand til på betryggende afstand af begivenhederne at følge eventuelle virkninger af mineudlægningerne, og for det andet kunne den skaffe sig oplysninger om allieret skibstrafik, om laster, afgange og destinationer for gode priseemner. Med hensyn til virkningen af mineudlægningen varede det ikke længe, før kaptajn Nerger med tilfredshed kunne notere sig resultaterne. Først opsnappedes et sigende telegram fra Cape Town: "Submarine off Cape Town". Grunden til denne overraskende og fejlagtige melding var netop minerne, og siden erfarede man på Wolf, at den engelske handelsflådes største skib Aquitania på 46.000 tons var gået under med 10.000 mand australske tropper. Ved den slags radioaflytning fik Wolf god tid til at forberede en opbringning af det udsete bytte, og herved kunne hjælpekrydseren prioritere sin krigsførelse, så den blev mest mulig følelig for de allierede.

Det gjaldt om, at hver opbringning blev udført så hurtigt og overraskende, at ofret hverken fik slået alarm eller sat sig til modværge. Metoden skulle vise sig effektiv hver eneste gang. 


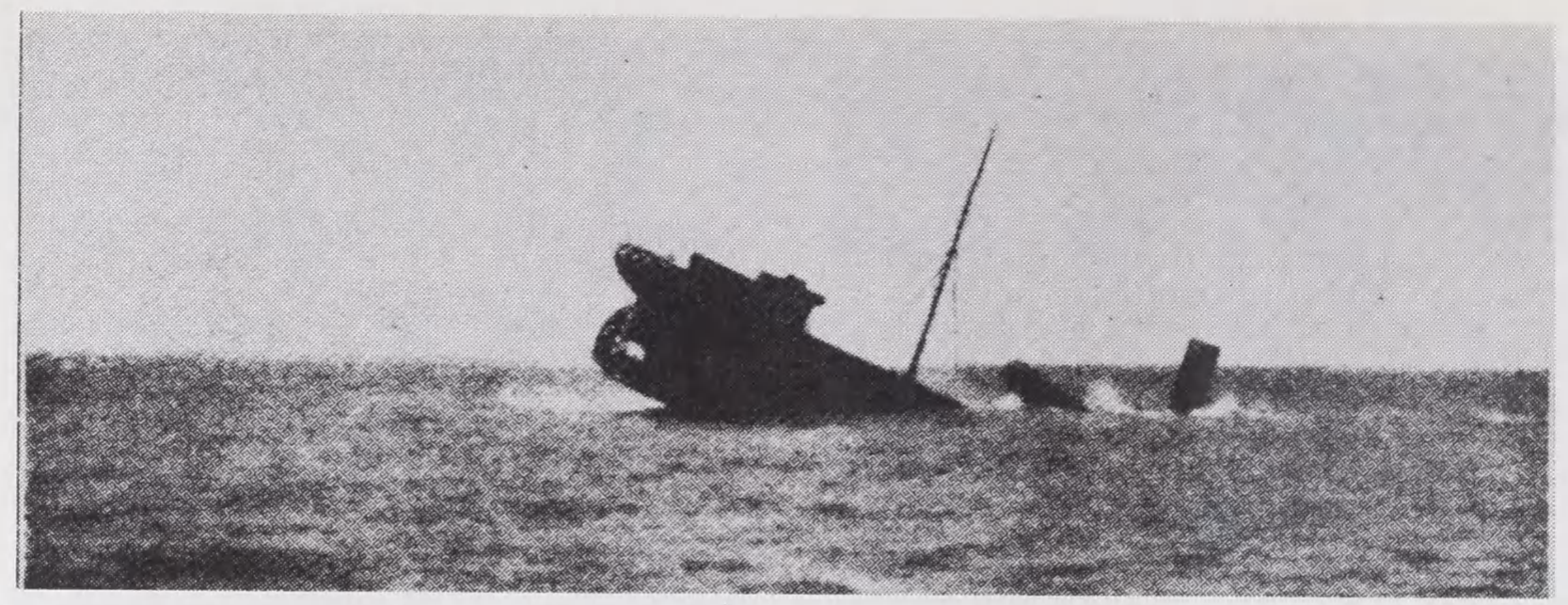

Den engelske kuldamper Jumna. Efter at være opbragt af Wolf og tømt for sin last af kul blev skibet sænket ved hjælp af sprængpatroner.

Når Wolf havde udvalgt sig et offer, oftest via aflytning af den allierede radiokommunikation, krydsede den på et givet tidspunkt ofrets rute. Uden at vække mistanke nærmede Wolf sig det fremmede skib. Når den var så tæt på modstanderen, at kanonerne kunne række, hejstes det tyske orlogsflag, rælingen fældedes og det fremmede skib fik et skud for boven. Samtidig signalerede man fra hjælpekrydseren, at skibet skulle stoppe, at det skulle undlade at bruge sin telegraf, at man ville sende en båd ombord. Mens skibet blev bordet for nærmere undersøgelse, sendte Wolf den lille vandflyver, der medførtes, på vingerne, således at man på krydseren kunne reservere sig mest mulig tid, hvis en røgfane eller et sejl i horisonten skulle afsløre, at et fremmed skib nærmede sig. En enkel gang lykkedes det ligefrem flyet at kapre en damper, da hjælpekrydseren ikke var i stand til at sejle på grund af kedelrensning. Under trussel om bombning fra luften valgte damperen at føje sig.

Så snart et skib var blevet opbragt, blev både last, besætning og eventuelle passagerer overført til Wolf, og skibet blev derefter sænket enten med sprængbomber i lasten eller ved kanonild. Wolf opbragte på denne måde i alt 14 dampere og sejlskibe, krigsførende såvel som neutrale. Et hovedprincip var, at ingen mennesker fra de opbragte skibe blev dræbt eller beordredes i redningsbådene.

Årsagen var ikke humanitet alene, men nok så meget kaptajn Nergers ønske om ikke at efterlade sig flere spor eller vidner end højst nødvendigt. Af samme grund lagde han vægt på, at ingen undslap fra hjælpekrydseren.

Ombord på Wolf blev fangerne anbragt i de lastrum, der ellers havde været brugt til opbevaring af de 500 miner, som Wolf havde haft med fra Kiel, og indenbords var der anbragt maskingeværer, der pegede direkte mod lugerne til lastrummene, således at man nemt kunne forhindre flugtforsøg eller nedkæmpe et fangeoprør. 
I takt med Wolfs succes som piratskib øgedes antallet af fanger drastisk, og i løbet af togtet nåede man op på mere end 200 fanger. Forholdene i lastrummene blev efterhånden meget barske, temperaturen var høj, den eneste ventilation kom fra en enlig elektrisk vifte, intet under at den fugtige luft hurtigt blev ulidelig tung og kvælende.

I kun ét tilfælde forsøgte et skib at sætte sig til modværge. Den japanske rutedamper Hitachi Maru var armeret med en enkelt kanon og forsøgte at tage kampen op mod Wolf, men den kunne ikke stille noget op mod hjælpekrydseren, idet Wolf hurtigt ramte dens skyts samt rummet, hvor telegrafen var anbragt.

16 japanske søfolk faldt ved denne korte træfning, hvorefter Hitachi Maru måtte give op. Selv om Hitachi Maru var blevet temmelig beskadiget, overførtes alligevel en del af fangerne til damperen, hvis aptering som passagerliner gjorde den velegnet som fangeskib. Herved lettedes situationen noget for fangerne, men da Igotz Mendi opbragtes, foretrak kaptajn Nerger alligevel at sænke Hitachi Maru.

Normalt har et krigsskib en vis aktionsradius, hvorpå det må forsynes, men de priser, som Wolf tog, forsynede den løbende med kul og proviant til den stadig voksende skare af fanger, og herved blev Wolf uafhængig af havne- og bunkerfaciliteter, således at den i princippet kunne holde søen, så længe det skulle være eller i det mindste så længe, den havde ammunition til sine torpedorør og kanoner. Da forbruget heraf skulle vise sig at være beskedent, har det næppe indvirket på togtets længde, som kom til at strække sig over mere end 16 måneder.

På dette fremrykkede tidspunkt af krigen havde Tyskland mere end nogensinde brug for sympati og sukces både på hjemmefronten og i den offentlige mening i de neutrale lande, hvilket ellers var vanskeligt nok, eftersom også den neutrale skibsfart ramtes hårdt af den uindskrænkede u-bådskrigsførelse, og det var derfor ikke så sært, at døvheden over for tyske synspunkter og meninger efterhånden blev ret udtalt $\mathrm{i}$ de fleste neutrale lande.

Fra 1.1.1917 havde tyske u-både uden varsel sænket ethvert skib, der vovede sig ind i krigszonen omkring De britiske Øer, hvad enten dette var neutralt eller fra Ententen. Denne form for krigsførelse betød ud over svære menneskelige og materielle tab, at Ententens krigspropaganda fik et virkningsfuldt nyt løft, ikke mindst i de neutrale lande. Danmark mistede således 305 skibe på i alt 281.834 br. tons tonnage, og 667 søfolk omkom. Imidlertid hører det med i billedet, at den allierede krigsførelse til søs næppe var mindre sart.

Ved siden af overfaldet på Belgien i 1914 var u-bådskrigen mod mere eller mindre forsvarsløse handelsskibe måske Ententens bedste propagandakort. 
Også i den danske medieverden og på det danske bogmarked havde den uindskrænkede ubådskrig fremkaldt en række pjecer og pamfletter af engelsk oprindelse, hvori den tyske u-bådskrigs rædsler udmaledes.

I denne situation var hjælpekrydserens bedrifter på verdenshavene velkomne for den tyske propagandamølle, thi her havde man en række spændende bedrifter, der til en vis grad drejede opmærksomheden bort fra den forhadte ubådskrig. Her var et eksempel på en tysk, human og gentleman-like søkrigsførelse. Nerger havde jo ikke såret eller dræbt nogen ud over den japanske kanonbesætning på Hitachi Maru. At Nerger overtrådte Genevekonventionen ved ikke at sætte sine fanger i land i første neutrale havn, er så en ganske anden sag, som naturligvis ikke blev berørt.

Men kaptajn Nerger havde jo i stedet taget samtlige besætninger fra de sænkede skibe ombord enten i Wolf eller i Igotz Mendi; tilmed havde han undgået opdagelse og havde ført sit skib sikkert i havn med et rigt bytte. Med andre ord en sømilitær bedrift, hvor snarrådighed, godt sømandsskab var forenet med en gentlemanlike krigsførelse, og Wolfs hjemkomst blev derfor iscenesat som et fuldkomment triumftog i Berlins gader. Fregattenkapitän Nerger og hele hans besætning marcherede gennem Brandenburger Tor ned ad Unter den Linden, fulgt af en stor menneskemængde. Foran Zeughaus kulminerede toget med, at kaptajn og besætning modtoges af kejserinden og kronprinsen.

Kort efter, eller næsten samtidig med denne hyldest i Berlin, må bogen om kaptajn Nergers bedrifter være udkommet i Berlin. Titlen lød: S.M.S. Wolfvom Kommandanten Fregattenkapitän Nerger, Druck und Verlag August Scherl, Berlin 1918.

I det eksemplar, som findes på Det kongelige Bibliotek, bekendtgøres det nederst på titelbladet, at bogen indgår i oplaget mellem "101 bis 200 Tausend". Det kan man vist kun betegne som en oplagssukces.

Men i Danmark udkom Fregattenkapitän Nergers bedrifter knap så hurtigt og i et noget mere beskedent oplag. Først hen i juli 1918 forelå den danske oversættelse af bogen: Fregattenkapitän Nerger, med Krydseren Wolf, oversat af Gertrud Rung, Nordiske Forfatteres Forlag, Kbh.1918.

Nergers beretning var langt fra et isoleret fænomen i krigsbogslitteraturen. Året før havde Nordiske Forfatteres Forlag udsendt korvetkaptajn grev v. Dohnas beretning om de togter, han gennemførte med hjælpekrydseren Möwe, der ganske som Wolf var et maskeret handelsskib, og i 1916 udsendtes historien om kaptajn Kønigs togt over Atlanterhavet i en stor ubevæbnet u-båd. Formålet med det sidstnævnte togt var således ikke af direkte militær art, men dels tjente 
turen deciderede propagandamæssige formål, dels var den et forsøg på at opretholde en spinkel livline til det neutrale U.S.A. For at historien kunne tjene sit propagandaformål, var den udformet som en veloplagt frisk fortælling om dådfuldt bravt sømandskab.

Da kaptajn Nergers bog udkom i Danmark, kom den tyske propaganda også ved denne lejlighed, som ved så mange andre, i kølvandet på den engelske, når det gjaldt forholdene på det danske bogmarked.

I Dansk Bogfortegnelse i ugen fra den 16. - 22. maj 1918 figurerede følgende titel: John Stanley Cameron: Paa kapertogt med "Wolf" og "Igotz Mendi". En amerikansk Skibskaptajns Beretning. (autoriseret Overs. for Danmark og Norge ved Otto Wadsted). Pios Boghandel - Povl Branner - København 1918.

Forfatteren var en af fangerne fra Igotz Mendi, der havde genvundet sin frihed på Skagens strand. I de 10 måneder, den amerikanske kaptajn John Stanley Cameron, hans hustru og deres fireårige datter Anita havde været fanger, havde de nået at have ophold både på Wolf, Hitachi Maru og til sidst på Igotz Mendi, og ud over ubehagelighederne herved havde kaptajn Cameron således de bedste forudsætninger til at kunne give en skildring af begivenhederne, sådan som han oplevede dem.

Den 9. juli 1917 var han blevet opbragt af Wolf. Cameron var da på vej fra San Francisco til Sydney i Australien, og da ca. 900 sømil fra sin rejses mål. John Stanley Cameron var skibsfører på den lille bark "Beluga", der var lastet med 15.000 dunke benzin. Egentligt havde han vendt sømandslivet ryggen, men et ønske om på en praktisk og billig måde at kunne besøge svigerforældrene i Australien gjorde, at han denne beklagelige 9. juli 1917 havde befundet sig på Beluga som kaptajn, ledsaget af kone og datter.

Der udkom således to bøger om de samme begivenheder, hvor der først kunne læses om dem set gennem den fangne amerikanske skibskaptajns briller og dernæst berettet ud fra den krigsførende, tyske Fregattenkapitän Nergers synsvinkel.

Det er vist ikke så almindeligt, at to bøger i den grad er synkrone, både med hensyn til emnet og det, der var det egentlige formål med dem: At vække sympati for henholdsvis Ententens og tyskernes synspunkter på krigen.

Fælles for begge bøger er imidlertid, at de ikke kan beskrives som banal rædselspropaganda, de rummer ingen hetz mod modparten. Med i billedet hører desuden, at det forlag, Nordiske Forfatteres Forlag, som kaptajn Nergers bog udkom på, helt og holdent blev drevet for tyske midler men med danske stråmænd ${ }^{2}$, således at forlagets rolle var sløret overfor offentligheden. Det betød, at man fra tysk side fik ganske gode muligheder for at kontrollere og bestemme 


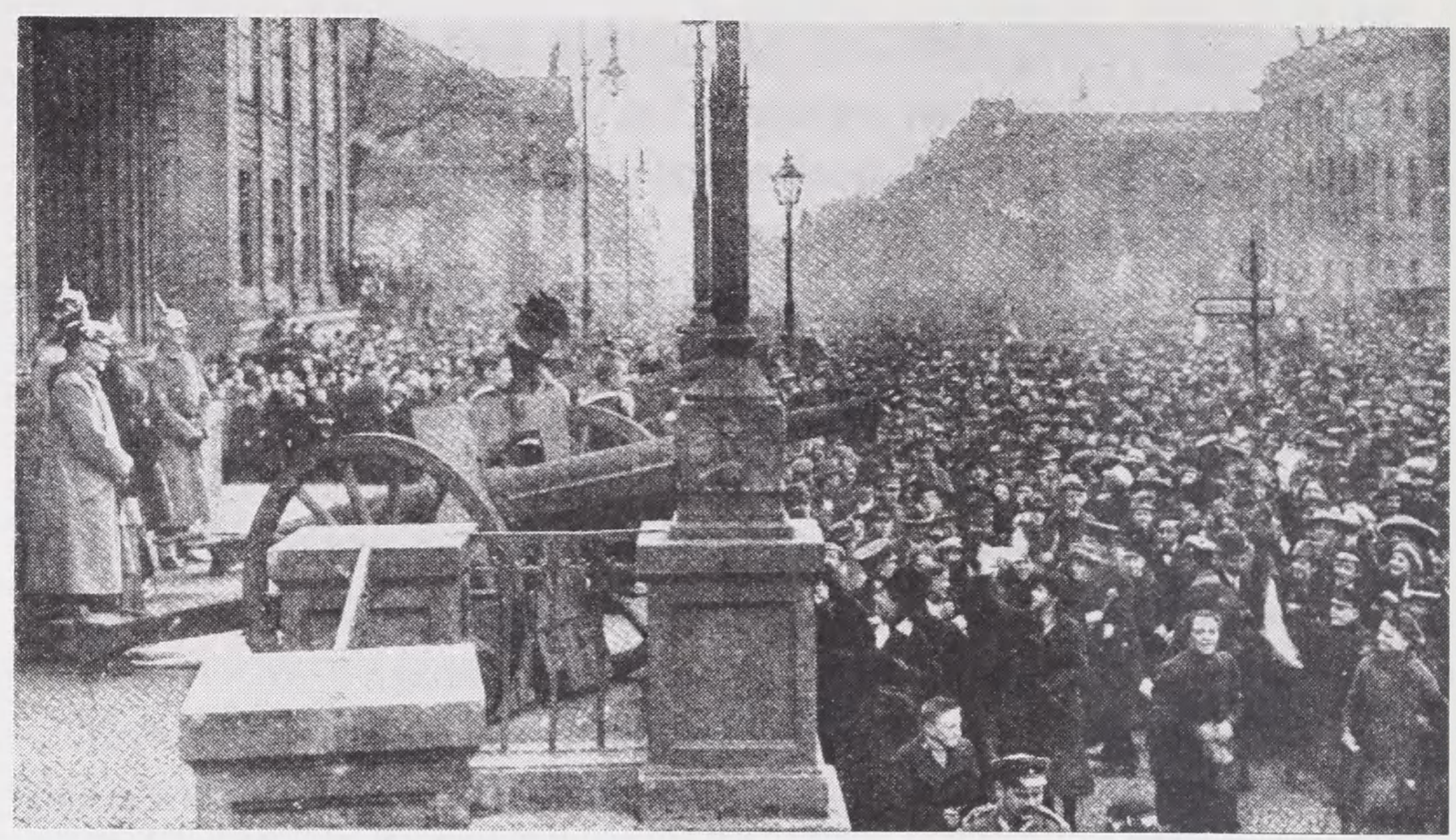

Fregattenkapitän Nerger og hans besætning modtages af kejserinden og kronprinsen på Zeughaus i Berlin.

kvaliteten i de af forlagets produkter, der skulle tale den tyske sag, og sådan som sympatien lå i Danmark, var det netop om at undgå alt for bastante virkemidler. Med kaptajn Nergers bog står vi overfor en beretning, der sandsynligvis har svaret til gesandtskabets forventning om saglig, afbalanceret propaganda.

I anslag og form minder både Camerons og Fregattenkapitän Nergers bøger ganske meget om den klassiske sørøverroman, selv om bøgerne naturligvis ikke er fiktionslitteratur. I dem begge låner Nerger visse træk fra "den ædle pirat", sådan som denne skikkelse kendes fra den klassiske piratlitteratur. Overfor både besætning og fanger fremstilles han som utilnærmelig og tavs. Ingen ved, hvad hans næste træk er, eller hvorhen skibet skal sejle; men midt i denne kulde er Fregattenkapitän Nerger tillige den humane pirat, der indskrænker sig til blot at tømme de skibe, han standser uden at gøre skibsbesætningerne eller passagererne fortræd.

Morsomt nok er disse karakteristika i Nergers egen beretning langt mindre fremtrædende end i Camerons, hvilket hænger sammen med skiftet i synsvinklen på begivenhederne, men grunden er nok også, at Nergers beretning formentligt er bygget på hans egen logbog, idet fremstillingen sine steder kan have noget tørt, rapportagtigt over sig.

Camerons bog er derimod ikke tør, måske fordi den i højere grad er lagt an som et "document humain", hvor begivenhederne ses og opleves af den fangne amerikanske skibskaptajn. Det han har oplevet ved sin tilfangetagelse er, ud 
over at det har været ubehageligt nok, tillige omgivet af en lidt eventyrlig aura som den, man ellers finder i Stevensons Skatteøen eller i kaptajn Marryats sømandsromaner. Naturligvis findes der i følge Camerons udlægning af begivenhederne også et modstykke til den ædle Fregattenkapitän. Det er Kapitänleutnant zur See, Helmuth Rose, der skildres som et gement menneske, helt blottet for format. Som prisekommandant på Igotz Mendi udfolder han, stadig efter Cameron, ud over en iøjnefaldende mangel på charme og humor, desuden en tåbelig formalistisk smålighed over for fangerne, der rækker lige fra simple dagligdags chikanerier til decideret udsultning. Da Igotz Mendi strander på Skagen, er det derfor mere end blot dårligt sømandskab eller vanheld for kaptajnløjtnant Rose. Det er i virkeligheden udtryk for en højere "poetisk retfærdighed", at Rose i stedet for at få jernkorset i Berlin må lade sig forsmædeligt internere i Danmark.

Kaptajn Camerons beretning udkom på Pios Forlag, et forlag, der ganske vist næp hentede direkte understøttelse i Storbritannien eller hos de øvrige ententelande, men som alligevel ensidigt publicerede krigslitteratur af engelsk, belgisk eller fransk oprindelse.

Sagen var, at der var penge også i den litterære del af krigen, hvad enten så midlerne kom fra en offentlig kasse, eller tilvejebragtes alene på merkantil basis. Allerede fra starten i 1914 havde det vist sig, at Ententen havde overtaget på det danske bogmarked. Grundene hertil var flere.

For det første var sympatien i Danmark i forvejen langt overvejende på Ententens side. Det uprovokerede tyske overfald på Belgien havde gjort et stærkt indtryk i Danmark, der med sine egne erfaringer fra 1864 og det deraf til stadighed mere eller mindre dårlige forhold til Tyskland, havde gjort det nemt at sætte sig i belgiernes sted. En stor rolle spillede det tillige, at tyskerne fra krigens begyndelse ikke var i stand til at koordinere eller styre en samlet indsats på propagandaområdet $\mathrm{i}$ udlandet. Den tyske propagandaindsats var i krigens start præget af mange hurtige og dermed dårligt forberedte initiativer, der i høj grad gjorde den tyske indsats både synlig og hørbar, uden at den derfor fik andet end negativ effekt.

I oktober 1914, to måneder efter krigens begyndelse, fandtes der hele 27 forskellige bureauer, der hver især beskæftigede sig med propaganda uden for Tyskland, uden at deres virksomhed på nogen måde var koordineret. Tværtimod syntes de til en vis grad at modarbejde hinanden. Intet under, at man kun i yderst ringe grad var i stand til at analysere eller blot vurdere forholdene og stemningen i Danmark ordentligt.

Eksempelvis havde man i begyndelsen af krigen masseuddelt aviser som 


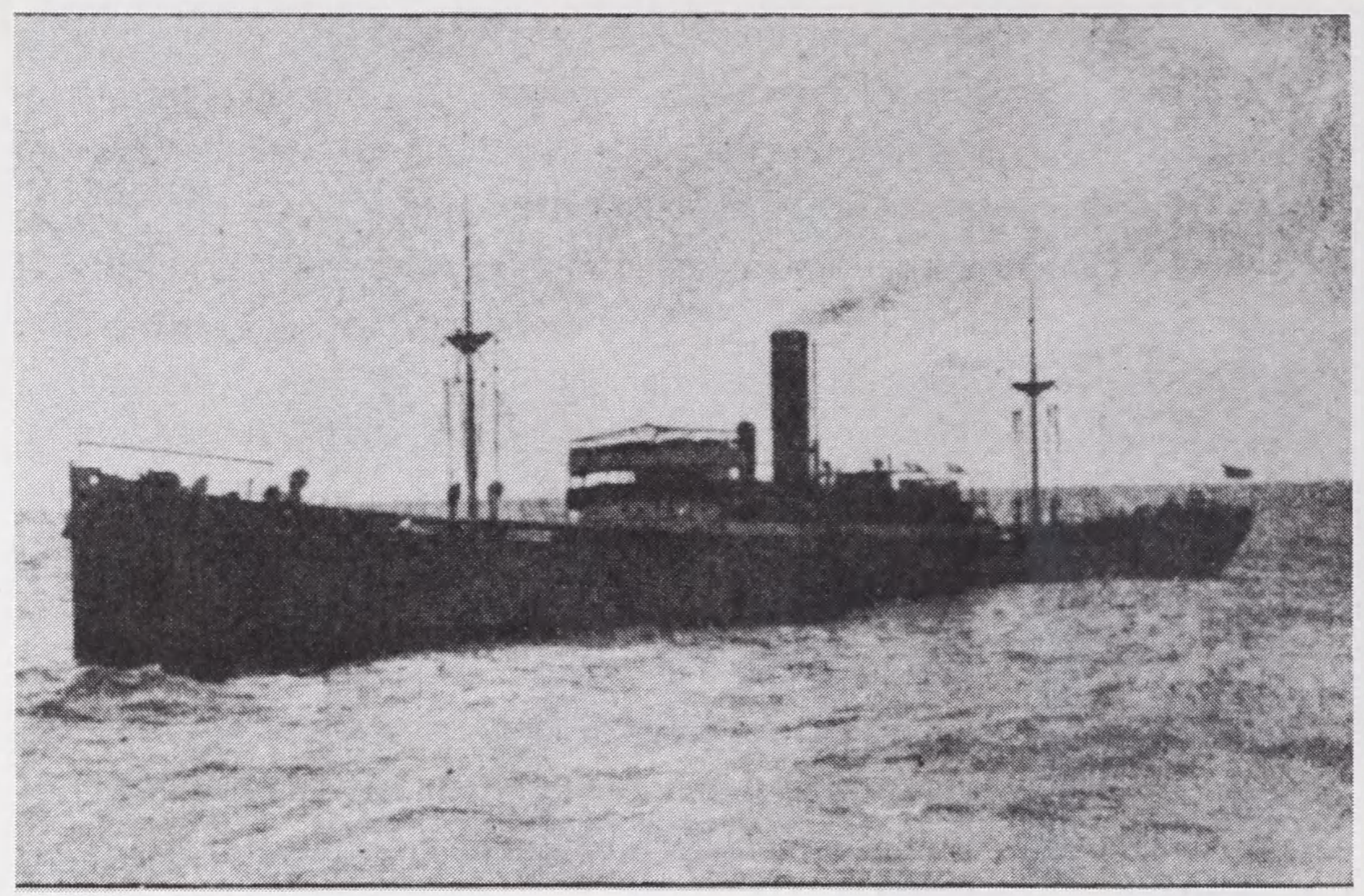

Den spanske damper Igotz Mendi.

Deutsche Tageszeitung, Post, Tägliche Rundschau i Danmark, idet man overså, at disse blade alle var stærkt præget af en antidansk politik i Nordslesvig. Lidt efter lidt blev denne indsats dog trimmet og bragt under kontrol, og de fleste propagandaaktiviteter i udlandet blev samlet i Zentralstelle für Auslandsdienst, der blev stillet under diplomaten friherre von Mumms ledelse.

Fik man således rådet bod på den organisatoriske misére, så lettede dette dog ikke på den kendsgerning, at de første krigsmåneders bastante indsats for Tysklands sag en gang for alle havde givet den danske offentlighed det indtryk, at den tyske propaganda var anmassende og stupid.

Den tyske gesandt i København, Ulrich Christian Brockdorff-Rantzau, gjorde sig ret hurtigt efter krigsudbruddet disse forhold klart, og han valgte derfor at føre en stærkt afdæmpet propagandapolitik med så få aktiviteter som muligt. I virkeligheden bestod en god del af hans indsats ligefrem $\mathrm{i}$ at forhindre eller undertrykke initiativer fra forskellige entreprenante danske eller tyske enkeltpersoner, der på hver sin måde ville gøre sig nyttige på propagandafronten.

Ved at gennemføre denne politik havde Brockdorff-Rantzau tillige en god udgangsposition overfor den danske udenrigsminister, Erik Scavenius, til at kræve tilbageholdenhed og afdæmpethed af den danske presse. Dette var allerede fra de første krigsmåneder den officielle politik på området fra tysk side, men linien var vanskelig at holde netop på grund af de mange uofficielle tyske 


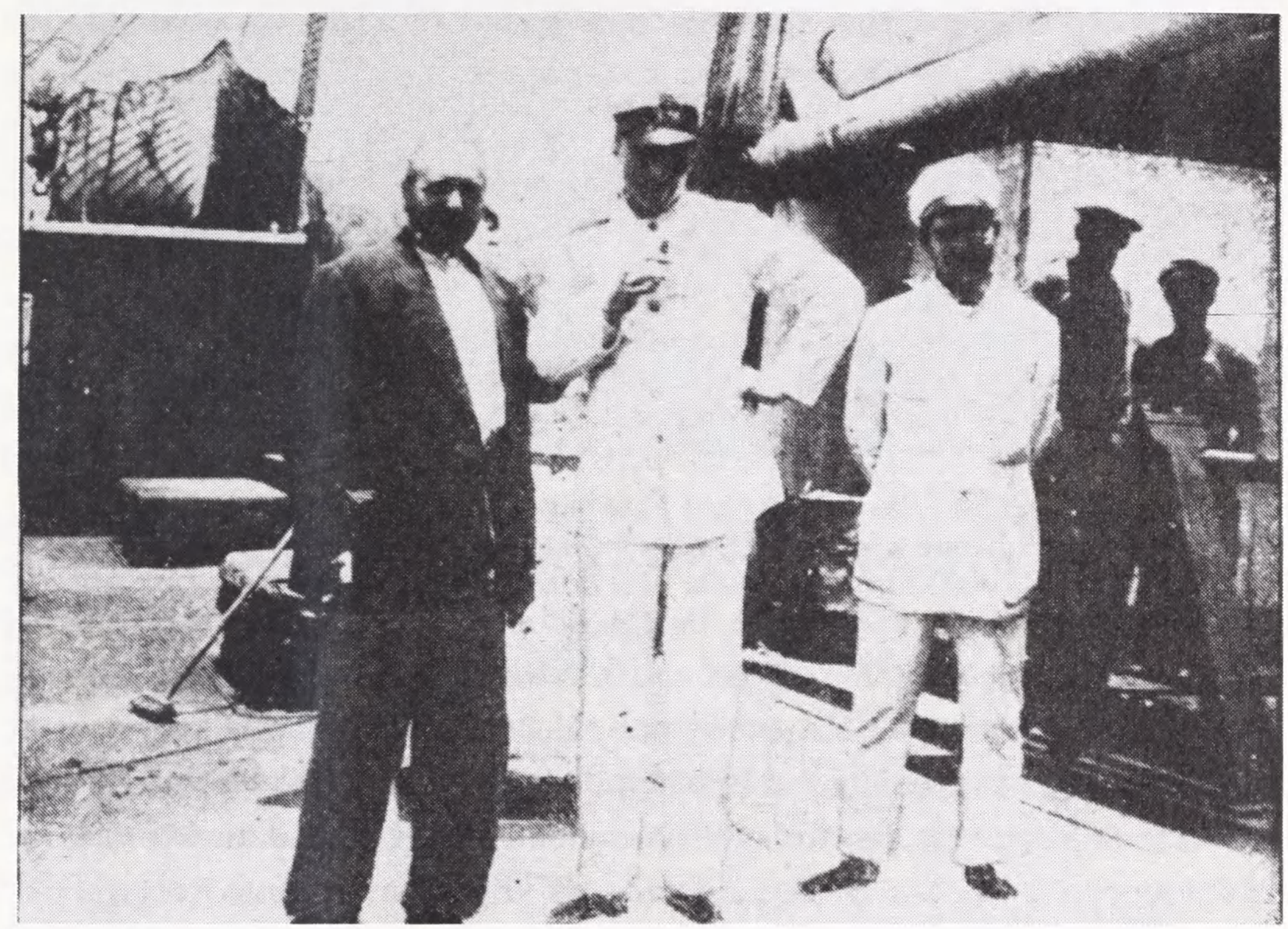

Prisekommandant Helmut Rose fotograferet på Igotz Mendi sammen med Igotz Mendis spanske kaptajn, samt endnu en tysk officer.

initiativer på feltet. Desuden havde nogle enkelte danske forfattere og kulturpersonligheder, bl.a. forfatteren Karl Larsen og tidsskriftredaktøren Louis von Kohl, også personlige eller økonomiske interesser i at antage sig den tyske sag, og det lykkedes trods gesandtens bestræbelser disse kulturpersonligheder at skabe sig en, i alt fald for en tid, ganske indbringende levevej. Dette var især tilfældet med Louis von Kohl, der bla. fik held til at vikle den tyske gesandt ind i et spil, hvor Brockdorff-Rantzau både økonomisk og propagandamæssigt kom til at gå betydeligt længere i Danmark, end han egentligt havde haft til hensigt. ${ }^{3}$

Etableringen af aktieselskabet Nordiske Forfatteres Forlag, hvor den danske oversættelse af Fregattenkapitän Nergers bog udkom, var netop i langt højere grad en følge af von Kohls manipulering af gesandten, end det var et resultat af målbevidst tysk planlægning. Forlaget, der oprindeligt var grundlagt af forfatteren Emil Rasmussen som enkeltmandsvirksomhed, blev af ham sammen med von Kohl og boghandleren Peter Hansen gjort til et aktieselskab i april 1917. Det financielle grundlag herfor, 20.000 kr, medbragte von Kohl direkte fra det tyske gesandtskab.

Efter omstruktureringen til aktieselskab udsendte forlaget sideløbende med 


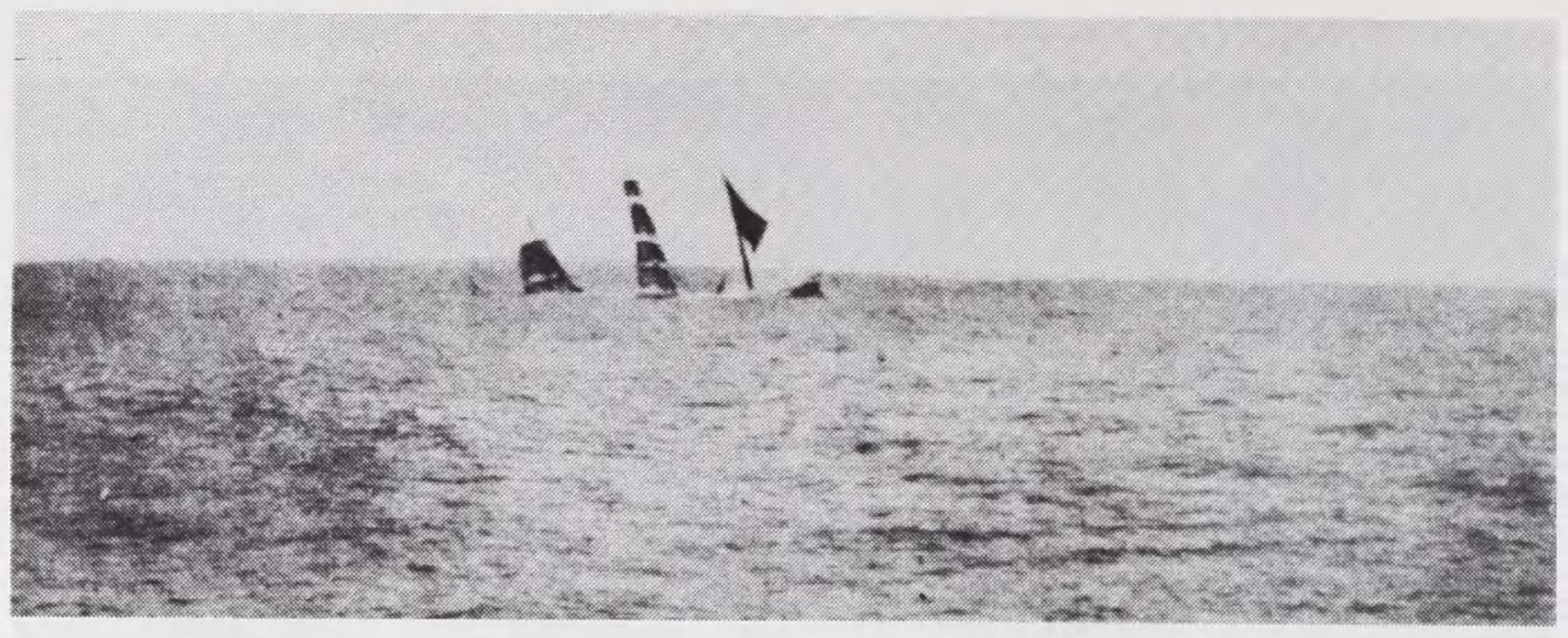

Fransk bark "Maréchal Davoust" sænkes. Den blev kapret 130 sømil syd for det gode håbs forbjerg. Den havde trådløs telegraf og førte to kanoner, men på grund af "Wolf"s fredelige udseende bestemte den sig først til at bruge kanonerne, da det var for sent.

Nergers beretning en række skrifter af umiskendelig tysk oprindelse garneret med ny dansk litteratur begået af mere eller - hvilket var det hyppigste - mindre talentfulde unge forfattere, der havde måttet indkassere afvisning på de større forlag. ${ }^{4}$

Derimod fungerede Pios forlag tilsyneladende ikke i kraft af direkte tilskud fra fremmede landes statskasser. Allerede før krigen havde dette foretagende indledt et udstrakt samarbejde med flere forlag og litterære agenter i England. Dette netværk skulle vise sig at blive til stor gavn gennem alle krigsårene. Ved siden af kaptajn Camerons beretning udsendte Pios Forlag en ganske stor mængde krigslitteratur, hvor ophavslandet var England.

I kataloget "Bøger der sælges mod ratebetaling" er der således opført 45 bøger, der særskilt i kataloget betegnes som bøger, der specielt omhandler krigen. I denne grupppe findes der alene af Kipling, hvis fleste bøger i forvejen kom på forlaget i dansk oversættelse, hele 6 titler: Den nye Hær, Frankrig i Krig, Fra Flaadens Overdrev, Undervandbaadenes Bedrifter, Krigen i Bjergene, Krigsliv til Søs.

Men i katalogets øvrige afsnit med anden litteratur findes desuden adskillige bøger, hvor titlen alene røber, at krigen og særligt ententelandenes syn på den er det centrale, hvad angår både emne og synsvinkel.

I virkeligheden kunne Pios udgivelsesprofil ikke have været mere proengelsk, hvis forlaget var blevet støttet direkte af engelske statsmidler.

Sådan tegnede det propagandamæssige landskab sig på dette sene tidspunkt af krigen, da beretningerne fra Wolf og Igotz Mendi publiceredes, men i øvrigt skulle denne type af krigsbøger vise sig at være en sejlivet genre.

Så sent som 1936 fulgte grev Felix Luckners bog Sødjævlen. Mit Livs Oplevelser. Luckners skildring er tæt på at være en pastiche over den klassiske eventyrerog piratroman. Her er alle ingredienserne: Den kvikke, vanartede søn, der løber 
hjemmefra for at stikke til søs og som gennem sømandslivets hårde skole modnes til et mandfolk, kapringer, strandinger på øde øer og dristige flugtforsøg fra velbevogtede fængsler. En særlig pointe er det, at hjælpekrydseren Sødjævelen tilmed var et rigtigt sejlskib, af type som skoleskibet Danmark, et tremastet barkskib.

Efter udgivelsestidspunktet, 1936 for den danske udgave, kunne man forestille sig, at bogen var et stykke nazi-propaganda, men dette er ikke tilfældet. Bogen udkom i Tyskland allerede i 1921, og selv om den forherliger det kejserlige Tyskland og dets flåde, er det først og fremmest sagens eventyrlige og romantiske side, der er fremherskende. Felix Luckner forlod tjenesten i flåden i 1921. Han levede siden af sin foredragsvirksomhed, som skulle fremme forsoning og forståelse mellem nationerne. I midten af trediverne fik han forbud af nazisterne mod at holde foredrag, og han mistede sin rang som Korvettenkapitän. Krigsårene tilbragte Luckner i Halle, og det lykkedes ham i foråret 1945 at redde Halle fra tilintetgørelse ved at træde i forbindelse med amerikanerne.

\section{Epilog}

Resten af historien har mindre at gøre med propagandaens og krigens rå virkelighed. Den foregår alene på forfængelighedens marked.

Den spanske regering var yderst taknemmelig over, at det var lykkedes at redde Igotz Mendi fra at falde i tyskernes hænder, og man ønskede meget forståeligt at synliggøre taknemmeligheden i form af en passende ordenstildeling til de involverede. I første række redningsfolkene fra Skagen, der havde bjerget fangerne og søofficererne fra den danske flåde, der havde handlet så resolut.

En enkel sag skulle man tro, men nej. Der skulle gå et helt år, før det gode danske embedsværk havde styr på den del af sagen, så de rigtige personer kunne få de rigtige udmærkelser, således at der ikke alene blev taget hensyn til den mulige heroisme i det givne øjeblik, men nok så meget til rang og anciennitet. Byfoged, politimester og konsul løb herefter med de mest vægtige udmærkelser, mens redningsfolk og søofficerer måtte nøjes med mere beskedne dekorationer. Alt gik ganske efter admiralens råd i Gilberts og Sullivans operette Pinafore:

I landsmænd her, som gerne vil nå op på vor samfundsstiges allerhøjeste top, flyd med, men hold jer i enhver forstand til stadighed og altid fra det dybe vand. Stå aldrig til søs! lad de andre stå! I får stribevis af kors og bånd og stjerner på! ${ }^{5}$ 
Noter:

1. Fregattenkapitän Nerger: Med Krydseren Wolf, oversat af Gertrud Rung, Nordiske Forfatteres Forlag, Kbh. 1918. S. 5.

2. Se min afhandling, Tyske forsøg på kulturpropaganda under den første Verdenskrig, Fund og Forskning, 26, 1982-83, s. 125 - 52 .

3. Smsts.

4. Smsts.

5. W.S. Gilbert og Arthur Sullivan: Den gode fregat Pinafore eller Ladyen og matrosen, Langkjærs Bogtrykkeri 1956.
Trykte kilder og arkivalier:

Handbuch der Auslandpresse, Berlin 1918.

Matthias Erzberger: Erlebnisse im Weltkrieg, Stuttgart 1920.

W. Nicolai: Nachrichtendienst, Presse und Volksstimmung im Weltkrieg, Berlin 1920.

Klaus Epstein: Matthias Erzberger and the Dilemma of German Democracy, Princeton 1959.

Kurt Koszyk: Deutsche Pressepolitik im Ersten Weltkrieg, Düsseldorf 1968.

Wolfgang Ruge: Matthias Erzberger: Eine politische Biographie, Berlin 1976.

Bangsbo Museet, Frederikshavn: Cloos Arkiv, Igotz Mendi.

Forlagsvæsen. Småtryk. Danske Afdeling. Det kongelige Bibliotek. 